\title{
POSÚDENIE BUDOVY Z HLADISKA UHLÍKOVEJ STOPY A CIRKULÁRNEJ EKONOMIKY
}

\author{
ASSESSMENT OF BUILDING IN TERMS OF CARBON FOOTPRINT AND CIRCULAR \\ ECONOMY
}

Jana Budajová*,1, Silvia Vilčekvá ${ }^{1}$, Peter Mésároš ${ }^{1}$

${ }^{*}$ jana.budajova@tuke.sk

${ }^{1}$ Technická univerzita v Košiciach, Stavebná fakulta, Ústav pozemného stavitel'stva, Vysokoškolská 4, 04200 Košice, Slovakia

\begin{abstract}
Abstrakt
Stavebný priemysel je primárny zdroj environmentálnych vplyvov, najmä uhlíkovej stopy. Hodnotenie životného cyklu (LCA) sa používa na hodnotenie vplyvu skúmanej budovy na životné prostredie. Náklady na životný cyklus (LCC) z pohl'adu cirkulárnej ekonomiky vytvárajú ekonomický model uprednostňujúci opätovné použitie a recykláciu. Ciel’om tohto príspevku je posúdit' rezidenčnú budovu z hl'adiska uhlíkovej stopy pomocou analýzy LCA a cirkulárnej ekonomiky pomocou analýzy LCC. Rezidenčná budova spôsobuje 1756 ton $\mathrm{CO}_{2 \mathrm{e}}$, čo predstavuje $41,35 \mathrm{~kg} \mathrm{CO} 2 \mathrm{e} / \mathrm{m}^{2} /$ rok. Celkové odhadované náklady životného cyklu budovy v nominálnom vyjadrení sú 1694 699,61 €. Priemerné celkové náklady životného cyklu 1 995,21 €/m².
\end{abstract}

\section{Kl’účové slová}

Uhlíková stopa, cirkulárna ekonomika, životný cyklus budov, náklady na životný cyklus

\begin{abstract}
The construction industry is the primary source of environmental impacts, especially the carbon footprint. Life cycle assessment (LCA) as an analytical method is used for quantifying the environmental impact of the investigated residential building. Life cycle costs (LCC) from the point of view of the circular economy create an economic model prioritizing reuse and recycling. The aim of this paper is to assess the residential building in terms of carbon footprint, using LCA analysis and circular economy, using LCC analysis. The residential building emits 1756 tons of $\mathrm{CO}_{2 \mathrm{e}}$, which represents $41.35 \mathrm{~kg} \mathrm{CO} \mathrm{CO}_{2} / \mathrm{m}^{2} /$ year. The total estimated life cycle cost of the building in nominal terms is $1694699.61 €$. This is the average total life cycle cost of $1995.21 € / \mathrm{m}^{2}$.
\end{abstract}

Key words

Carbon footprint, circular economy, life cycle assessment, life cycle costs

\section{1 ÚVOD}

Nadmerné využívanie dostupných zdrojov a neustále sa rozvíjajúce mestá mali dôsledky v podobe znečistenia a nerovnováhy životného prostredia. Stavebný priemysel a jeho miestne a globálne dodávatel'ské ret'azce sú zodpovedné za značné množstvo nesprávneho pridel'ovania zdrojov a využívania energie v kombinácii s emisiami skleníkových plynov (GHG). Udržatel’nost' je široký pojem zahŕňajúci tri aspekty - ochranu životného prostredia, sociálnu rovnost' a ekonomickú bezpečnost'. Cirkulárna ekonomika je nevyhnutným predpokladom udržatel'nosti [1]. Cirkulárna ekonomika (CE) poskytuje širokú škálu riešení na predíženie životnosti budov s ciel'om oddelit' vplyv na životné prostredie a ekonomický rast znížením spotreby surovín a predchádzaním vzniku odpadu udržiavaním hodnoty produktov čo najdlhšie. V strednej Európe je potrebné posunút' sa smerom k správnej hierarchii odpadu, od recyklácie po predchádzanie vzniku odpadu a opätovné použitie produktov a komponentov. Jedným zo spôsobov podpory CE by mohlo byt' hodnotenie životného cyklu (LCA), ktoré sa stáva súčast'ou predpisov a stáva sa kl'účovým nástrojom environmentálneho manažmentu v stavebníctve [2]. Stavebníctvo tvorí až $39 \%$ celkových emisií $\mathrm{CO}_{2}$ a približne $35 \%$ celkového toku odpadu zo skládok [3]. LCA sa v súčasnosti vo vel'kej miere využíva na hodnotenie vplyvov budov a zastavaného prostredia na životné prostredie vzhl'adom na rastúci záujem o využívanie zdrojov v stavebníctve; spotreba energie počas ich prevádzky; likvidácia odpadu po skončení životnosti budov a súvisiace environmentálne dôsledky [4]. Tento článok hodnotí rezidenčnú budovu 
z hl'adiska uhlíkovej stopy pomocou LCA a CE jej vplyv na životné prostredie a ekonomiku. Môže byt' budova bez negatívnych vplyvov na životné prostredie zároveň predražená? Túto otázku kladiem v tomto článku.

\section{UHLÍKOVÁ STOPA}

Pojem uhlíková stopa sa používa na označenie celkového množstva emisií $\mathrm{CO}_{2}$ a iných skleníkových plynov (GHG), za ktoré je zodpovedná osoba alebo organizácia. Uhlíkovú stopu teda možno charakterizovat' ako celkové množstvo $\mathrm{CO}_{2}$ a iných skleníkových plynov emitovaných počas životného cyklu produktu alebo služby [5]. Uhlíková stopa je podkategóriou ekologickej stopy [6].

Podl'a Kjótskeho protokolu existuje šest' hlavných skleníkových plynov s potenciálom spôsobit’ zmenu klímy, pričom každý z nich má iný potenciál globálneho otepl'ovania. Na ul'ahčenie bola vplyvu otepl'ovania $\mathrm{CO}_{2}$ priradená hodnota jedna a potenciál globálneho otepl'ovania iných skleníkových plynov sa použiva na premenu bezuhlíkových plynov na ekvivalenty $\mathrm{CO}_{2}[5]$.

\section{Potenciál globálneho otepl'ovania (GWP)}

Potenciál globálneho otepl'ovania (GWP) spôsobený emisiami skleníkových plynov sa vzt’ahuje na oxid uhličitý $\mathrm{CO}_{2}$ a vyjadruje sa ako ekvivalent oxidu uhličitého $\mathrm{CO}_{2 \mathrm{e}}$ [7]. Pomocou GWP môžeme určit' uhlíkovú stopu produktu. GWP je tol'ko tepla (infračerveného žiarenia) kol'ko zachytí jednotka skleníkového plynu v atmosfére počas daného obdobia v porovnaní s tým, čo je zachytené v rovnakom množstve oxidu uhličitého $\left(\mathrm{CO}_{2}\right)[8]$.

\section{Hodnotenie životného cyklu (LCA)}

Uhlíková stopa môže byt' hodnotená pomocou metódy LCA a vyjadrená prostredníctvom potenciálu globálneho otepl'ovania GWP. Životný cyklus budovy zahŕňa všetky etapy od jej vzniku cez vývoj počas života až po jej zánik. Naším ciel'om je preto znižovat' vplyv budov na životné prostredie počas celého životného cyklu budov [9].

Analýza životného cyklu budovy je riešená metódou LCA, ktorá hodnotí vplyv výstavby od prvej etapy t’ažby, získavania materiálu, výroby stavebných konštrukcií cez zat’aženie počas prevádzky a aktívnej životnosti budovy až po likvidáciu odpadu a demoláciu [10 ]. Podl’a tohto hodnotenia je možné stavbu posúdit' v rámci systémových hraníc:

- od kolísky po bránu" alebo "od kolísky po bránu s možnost’ami",

- "od kolísky po hrob"

- $\quad$ "od kolísky ku kolíske" [9].

\section{Náklady na životný cyklus (LCC)}

Náklady na životný cyklus sa môžu vykonávat’ v ktorejkol’vek fáze životného cyklu budovy. Náklady na životný cyklus (LCC) sú celkové náklady spojené s projektovaním a výstavbou budovy, prevádzkou a údržbou budovy, s výnimkou nákladov spojených s demoláciou budovy na konci jej životného cyklu.

Medzinárodná norma ISO 15686-5: 2008 poskytuje jasnú štruktúru rozpisu nákladov na zložky nákladov životného cyklu budovy, ktorá zahŕňa štyri hlavné kategórie, ktorými sú: 1. náklady na návrh a výstavbu, 2. prevádzkové náklady, 3. náklady na údržbu a 4. koniec - životné náklady. V rámci každej kategórie sú navrhnuté podrobnejšie zložky nákladov na pokrytie všetkých relevantných nákladov spojených s vlastníctvom budovy počas jej životného cyklu [11].

\section{METÓDY A MATERIÁLY}

\section{Prípadová štúdia - rezidenčná budova}

Rezidenčná budova sa nachádza v Poprade. Hrubá podlahová plocha je $849,38 \mathrm{~m}^{2}$ na štyroch podlažiach. Budova je súčast’ou komplexu štyroch rovnakých bytových domov a spĺn̆a tepelnotechnické požiadavky pre kategóriu A0 (nulová budova). Stavba má murovaný nosný systém z pálených tehál; stropy sú tvorené železobetónovými doskami hrúbky $160 \mathrm{~mm}$. Budova je zateplená izoláciou Greywall EPS (expandovaný polystyrén). Hodnoty energetickej spotreby budovy sú $42,4 \mathrm{kwh} / \mathrm{m}^{2}$ a elektrickej energie a $68,8 \mathrm{kwh} / \mathrm{m}^{2}$. Uhlíková stopa obytnej budovy 
bola vypočítaná na $1 \mathrm{~m}^{2}$ podlahovej plochy za obdobie 50 rokov. Materiály použité v rezidenčnej budove, ich množstvo a cena sú uvedené v tab. 1 .

Tab. 1 Materiály, množstvo a náklady.

\begin{tabular}{|c|c|c|c|c|c|c|c|}
\hline CLASS & QUANTITY & UNIT & $€$ & CLASS & QUANTITY & UNIT & $€$ \\
\hline FOUNDATION & & & & BEAM & & & \\
\hline Aggregate (crushed & & & & Ready-mix concrete & & & \\
\hline gravel) & 19,272 & $\mathrm{~m}^{3}$ & 559 & $\mathrm{C} 25 / 30$ & 164,784 & $\mathrm{~m}^{3}$ & 24965 \\
\hline Ready-mix concrete & & & & Reinforcement steel & & & \\
\hline $\mathrm{C} 16 / 20$ & 13,178 & $\mathrm{~m}^{3}$ & 1996 & (rebar) & 5,863 & ton & 3548 \\
\hline Ready-mix concrete & & & & Reinforcement steel & & & \\
\hline $\mathrm{C} 25 / 30$ & 42,268 & $\mathrm{~m}^{3}$ & 6404 & (rebar) & 12,583 & ton & 7614 \\
\hline Reinforcement steel & & & & Ready-mix concrete & & & \\
\hline (rebar) & 1,82 & ton & 1101 & $\mathrm{C} 25 / 30$ & 5,148 & $\mathrm{~m}^{3}$ & 776 \\
\hline Ready-mix concrete & & & & Reinforcement steel & & & \\
\hline $\mathrm{C} 25 / 30$ & 99,74 & $\mathrm{~m}^{3}$ & 15111 & (rebar) & 0,651 & ton & 394 \\
\hline & & & & Ready-mix concrete & & & \\
\hline Formwork blocks & 5,825 & $\mathrm{~m}^{2}$ & 79 & $\mathrm{C} 25 / 30$ & 3,229 & $\mathrm{~m}^{3}$ & 489 \\
\hline Formwork blocks & 63,9 & $\mathrm{~m}^{2}$ & 746 & $\begin{array}{l}\text { Reinforcement steel } \\
\text { (rebar) }\end{array}$ & 0,361 & ton & 218 \\
\hline $\begin{array}{l}\text { Reinforcement steel } \\
\text { (rebar) }\end{array}$ & 0,628 & ton & 380 & $\begin{array}{l}\text { PVC roofing } \\
\text { membrane }\end{array}$ & 324 & $\mathrm{~m}^{2}$ & 2494 \\
\hline Aggregate (crushed & & & & & & & \\
\hline gravel) & $\begin{array}{l}39,875 \\
52,65\end{array}$ & $\mathrm{~m}^{3}$ & $\begin{array}{l}1156 \\
45\end{array}$ & $\begin{array}{l}\text { Geotextile } \\
\text { EPS } 150 \mathrm{~mm}\end{array}$ & $\begin{array}{l}324 \\
119\end{array}$ & $\mathrm{~m}^{2}$ & $\begin{array}{l}279 \\
827\end{array}$ \\
\hline Geotextile & 52,65 & $\mathrm{~m}^{2}$ & 45 & EPS $150 \mathrm{~mm}$ & 11,9 & $\mathrm{~m}^{3}$ & 827 \\
\hline Geotextile & 66,603 & $\mathrm{~m}^{2}$ & 57 & EPS $150 \mathrm{~mm}$ & 17,2 & $\mathrm{~m}^{3}$ & 1195 \\
\hline Asphalt penetration & & & & & & & \\
\hline varnish & 70,042 & $\mathrm{~kg}$ & 538 & PIR insulation $200 \mathrm{~mm}$ & 232 & $\mathrm{~m}^{2}$ & 3371 \\
\hline EXTERNAL & & & & Asphalt roofing & & & \\
\hline WALL & & & & membrane & 262 & $\mathrm{~m}^{2}$ & 1782 \\
\hline Clay brick 25 & 190,127 & $\mathrm{~m}^{3}$ & 21945 & $\begin{array}{l}\text { Bitumen roofing } \\
\text { membrane }\end{array}$ & 262 & $\mathrm{~m}^{2}$ & 1782 \\
\hline Clay brick 20 & 27,832 & $\mathrm{~m}^{3}$ & 1548 & Penetration & 68 & $\mathrm{~kg}$ & 143 \\
\hline Clay brick 25 & 52,93 & $\mathrm{~m}^{3}$ & 3460 & $\begin{array}{l}\text { Oriented strand board } \\
\text { (OSB) }\end{array}$ & 262 & $\mathrm{~m}^{2}$ & 2835 \\
\hline Clay brick 2 in 1 & 7,057 & $\mathrm{~m}^{3}$ & 815 & PE foil & 809,12 & $\mathrm{~m}^{2}$ & 785 \\
\hline Masonry lintel & 2 & $\mathrm{~m}$ & 23 & EPS $100 \mathrm{~s} 50 \mathrm{~mm}$ & 214,19 & $\mathrm{~m}^{2}$ & 169 \\
\hline Masonry lintel & 85 & $\mathrm{~m}$ & 988 & EPS $100 \mathrm{~S} 100 \mathrm{~mm}$ & 214,19 & $\mathrm{~m}^{2}$ & 169 \\
\hline Masonry lintel & 3 & $\mathrm{~m}$ & 35 & $\begin{array}{l}\text { EPS acoustic floor slab } \\
\text { Rock wool insulation }\end{array}$ & 2,681 & $\mathrm{~m}^{2}$ & 3 \\
\hline Clay brick 11,5 P10 & 318,396 & $\mathrm{~m}^{3}$ & 15824 & panels & 623,095 & $\mathrm{~m}^{2}$ & 683 \\
\hline Clay brick 14 P10 & 264,689 & $\mathrm{~m}^{2}$ & 1779 & FINISH & & & \\
\hline Formwork blocks & 30,03 & $\mathrm{~m}^{2}$ & 1779 & Lime plaster & 480 & $\mathrm{~kg}$ & 62 \\
\hline Aerated concrete & 38,64 & $\mathrm{~m}^{2}$ & 804 & Penetration & 3011,254 & $\mathrm{~m}^{2}$ & 6324 \\
\hline Extruded & & & & Acrylic dispersion & & & \\
\hline polystyrene (XPS) & 70,8 & $\mathrm{~m}^{2}$ & 1415 & paint & 140 & $\mathrm{~kg}$ & 672 \\
\hline $\begin{array}{l}\text { EPS } 70 \text { F } 100 \mathrm{~mm} \\
\text { Greywall EPS } 100\end{array}$ & 90,8 & $\mathrm{~m}^{2}$ & 579 & $\begin{array}{l}\text { Dispersion-based } \\
\text { interior paints } \\
\text { Reinforcement steel }\end{array}$ & 2200 & $\mathrm{~kg}$ & 10560 \\
\hline $\mathrm{mm}$ & 61,546 & $\mathrm{~m}^{2}$ & 478 & (rebar) & 9,6 & ton & 5856 \\
\hline Greywall EPS 150 & & & & DPL laminated & & & \\
\hline $\mathrm{mm}$ & 612,866 & $\mathrm{~m}^{2}$ & 7141 & flooring & 618,375 & $\mathrm{~m}^{2}$ & 2962 \\
\hline Greywall EPS 180 & & & & & & & \\
\hline $\mathrm{mm}$ & 59,024 & $\mathrm{~m}^{2}$ & 825 & Ceramic tiles & 231,663 & $\mathrm{~m}^{2}$ & 1297 \\
\hline SITE & & & & Waterproofing & 217,492 & $\mathrm{~m}^{2}$ & 1183 \\
\hline
\end{tabular}




\begin{tabular}{|c|c|c|c|c|c|c|c|}
\hline \multicolumn{8}{|l|}{ Ready-mix concrete } \\
\hline $\mathrm{C} 12 / 15$ & 2,808 & $\mathrm{~m}^{3}$ & 510 & Silica (sand) & 30,552 & $\mathrm{~kg}$ & 5 \\
\hline Aluminium plinth & 68,3 & $\mathrm{~m}$ & 464 & Silicone resin plaster & 95,475 & $\mathrm{~kg}$ & 372 \\
\hline Aggregate (crushed & & & & & & & \\
\hline gravel) & 5,265 & $\mathrm{~m}^{3}$ & 153 & Screed mortar & 1737 & $\mathrm{~kg}$ & 499 \\
\hline OTHER & & & & Screed mortar & 722 & $\mathrm{~kg}$ & 207 \\
\hline Ready-mix concrete & & & & & & & \\
\hline $\mathrm{C} 25 / 30$ & 6,889 & $\mathrm{~m}^{3}$ & 1044 & Screed mortar & 2000 & $\mathrm{~kg}$ & 574 \\
\hline Reinforcement steel & & & & & & & \\
\hline (rebar) & 0,766 & ton & 464 & Ready mix screed & 21976,071 & $\mathrm{~kg}$ & 31138 \\
\hline DOOR and WINDOW & & & & Textile mesh & 71,971 & $\mathrm{~m}^{2}$ & 297 \\
\hline External door & 26,792 & $\mathrm{~m}^{2}$ & 0 & Silicone resin plaster & 1904,1 & $\mathrm{~kg}$ & 3515 \\
\hline External door & 27 & $\mathrm{~m}^{2}$ & 3828 & Lime-cement plaster & 71000 & $\mathrm{~kg}$ & 9230 \\
\hline External door & 87 & $\mathrm{~m}^{2}$ & 7846 & Dry mortar mixture & 3200 & $\mathrm{~kg}$ & 4368 \\
\hline Window & 173,51 & $\mathrm{~m}^{2}$ & 34876 & Lime-cement plaster & 14000 & $\mathrm{~kg}$ & 1820 \\
\hline Interior door & 86,68 & $\mathrm{~m}^{2}$ & 0 & Glass fibre mesh & 89,02 & $\mathrm{~m}^{2}$ & 191 \\
\hline
\end{tabular}

\section{LCA analýza}

$\mathrm{Na}$ analýzu vplyvov budovy na životné prostredie bol použitý softvér One Click LCA, ktorý pracuje v súlade s EN 15987, STN EN ISO 14040 a ISO 14044 pre systémovú hranicu „od kolísky po bránu s možnost’ami“. Vplyvy na životné prostredie boli zist'ované na celkovej podlahovej ploche budovy za obdobie 50 rokov. Hodnotenie LCA zahŕňa tieto fázy: etapa produktu (A1-A3), doprava z výroby na stavenisko (A4), výmena (B4), renovácia (B5), spotreba energie (B6), spotreba vody (B7), fáza konca životnosti (C1-C4), modul D.

\section{LCC analýza}

Kalkulácia životného cyklu sa vykonáva pomocou softvéru One Click LCA v súlade s normou ISO 15686-5 pri dodržaní štruktúry normy EN 16627. Analýza nákladov životného cyklu zahŕňa fázu produktu (A0 - A5), výmenu (B4), renováciu (B5), prevádzkovú spotrebu energie (B6), prevádzkovú spotrebu vody (B7) a fázu konca životnosti (C1-C4).

\section{VÝSLEDKY A DISKUSIA}

\section{LCA - potenciál globálneho otepl'ovania GWP}

V kategórii GWP má najväčší podiel na emisiách $\mathrm{CO}_{2 \mathrm{e}}$ prevádzková energetická fáza $\mathrm{B} 6$ až 78,6 \%, nasleduje produktová fáza s $13 \%$, kde najnegatívnejší vplyv na vývoj majú použité tehly, malty a potery 25,5\% a 18,1\%. životné prostredie. Fázou s najnižším podielom $\mathrm{CO}_{2 \mathrm{e}}$ je doprava s podielom $0,6 \%$. Spotreba elektriny a energie sú hlavnými prispievatel'mi $\mathrm{CO}_{2 \mathrm{e}}$.

Celý objekt komplexne vytvára emisie $\mathrm{CO}_{2 \mathrm{e}} \mathrm{v}$ rozsahu 1756 ton $\mathrm{CO}_{2 \mathrm{e}}$, čo je 41,35 kg CO $2 \mathrm{e} / \mathrm{m}^{2} /$ rok. Etapy, ktoré najviac prispievajú $\mathrm{k}$ uhlíkovej stope, sú prevádzková energia B6, produkt A1-A3 a obnova a renovácia B4-B5. Fáza transportu A4 najmenej vplýva na emisie. Výsledky sú uvedené na obrázkoch 1 a 2.

\section{LCC výsledky}

Celkové odhadované náklady životného cyklu budovy v nominálnej hodnote sú 1694 699,61 €. Celkové náklady životného cyklu na hrubú podlahovú plochu sú 1 995,21€/ $\mathrm{m}^{2}$ (1 694 699,61 €/849,5 m²). Tabul'ka Tab. 1 poskytuje celkový súhrn odhadovaných nákladov na životný cyklus a hmotnosti. Náklady na energiu tvoria 52,0 \% z celkového rozpočtu životného cyklu. Okrem nákladov na energie predstavujú náklady na výstavbu 16,8 \% a náklady na údržbu budovy $17,5 \%$. 


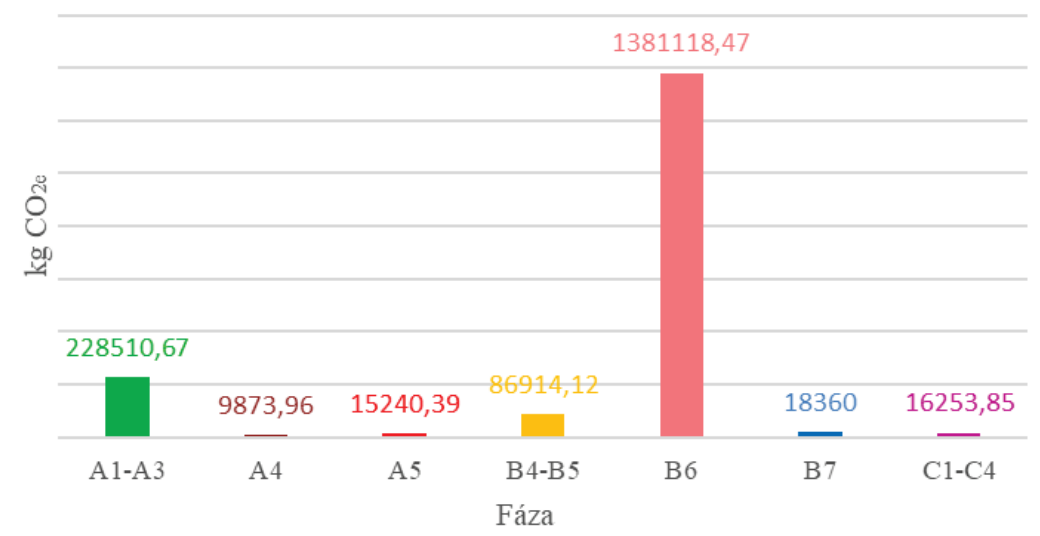

Obr. 1 Potenciál globálneho otepl'ovania GWP.

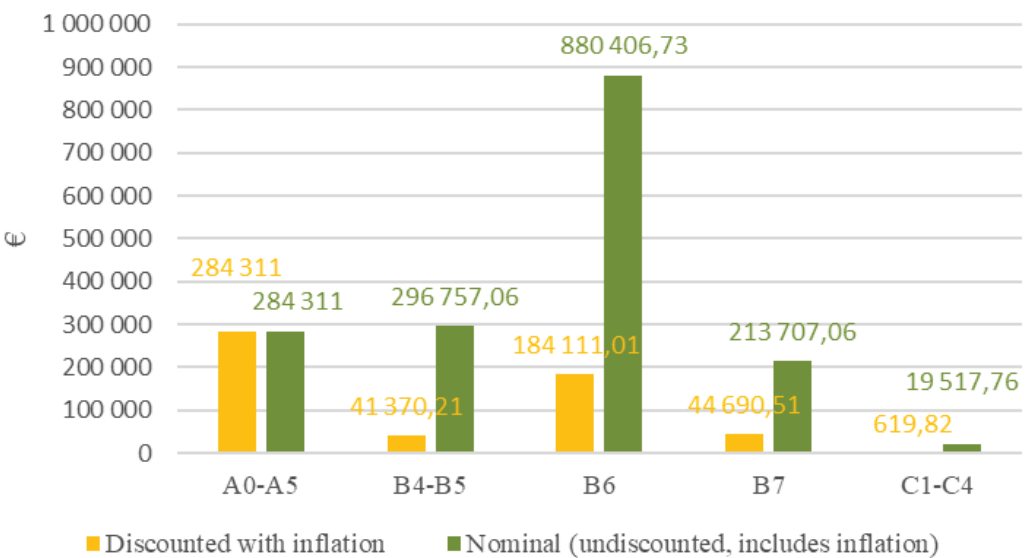

Obr. 2 Náklady na životný cyklus stavby.

\section{Diskusia}

Uhlíková stopa rezidenčnej budovy bola určená prostredníctvom GWP pomocou LCA. Predpokladaná životnost' bola vypočítaná na obdobie 50 rokov, čo sa bežne používa pri hodnotení LCA v stavebníctve. Celá budova produkuje emisie $\mathrm{CO}_{2 \mathrm{e}} \mathrm{V}$ rozsahu 1756 ton, čo predstavuje $41,35 \mathrm{~kg} \mathrm{CO} 2 \mathrm{e} / \mathrm{m}^{2} / \mathrm{rok}$ a $2065 \mathrm{~kg} \mathrm{CO} \mathrm{CO}_{2} / \mathrm{m}^{2}$. V porovnaní so štúdiou rezidenčných budov z juhovýchodného Turecka [12], ktorá hodnotí 5-poschodovú budovu a 13poschodovú budovu, spôsobuje budova hodnotená na Slovensku menej emisií $\mathrm{CO}_{2 \mathrm{e}}$. Rozsahy emisií v budovách sa pohybujú od 3956 do $5809 \mathrm{~kg} \mathrm{CO} 2 \mathrm{e} / \mathrm{m}^{2}$.

V budovách sa posudzovali aj náklady na životný cyklus. Celkové náklady na životný cyklus sa odhadujú na 7,28 milióna USD, čo je 6,4 milióna $€$ pre 5-poschodovú budovu a 1,72 milióna USD, čo je 1,5 milióna $€$ pre 13-poschodovú. Náklady na stavbu tvoria 52-49\% z celkových LCC, pričom najdrahšie položky sú základy a podlahy. V porovnaní s riešenou stavbou na Slovensku, ktorá má celkové odhadované náklady životného cyklu 1,69 mil. €, majú vyššie náklady [12].

\section{ZÁVER}

Stavebné konštrukcie sa vyrábajú zo širokého spektra zdrojov energeticky náročnými procesmi, od t’ažby surovín až po konečnú fázu likvidácie. Energeticky náročné procesy spotrebúvajú vel'ké množstvo energetických zdrojov a produkujú značné emisie a odpad. Vplyvy na životné prostredie spojené s výstavbou zahíňajú t’ažbu materiálu, 
prepravu, výrobu produktu, fázu prevádzky, obnovu, koniec životnosti a recykláciu. Tieto fázy majú tiež značné ekonomické náklady. Posúdenie vplyvu na životné prostredie a nákladov na budovu ako celok je zložitá úloha, pretože si vyžaduje posúdenie všetkých jej prvkov a štádí životného cyklu [13]. Výsledky tejto štúdie poukazujú na to, že na uhlíkovej stope sa najviac podiel'a prevádzková energia $(78,6 \%)$ a zároveň najväčšie náklady spôsobuje prevádzková energia. Množstvo emisií $\mathrm{CO}_{2 \mathrm{e}}$ je ovplyvnené nielen výberom materiálov, ale aj celkovou hrubou podlahovou plochou. Budúce výskumné práce budú zamerané na hĺbkovú analýzu a porovnanie environmentálnych a ekonomických aspektov viacerých budov s ciel'om nájst' environmentálne priaznivé opatrenia.

\section{Pod'akovanie}

Táto štúdia bola finančne podporená Grantovou agentúrou Slovenskej republiky na podporu projektu č. 1/0512/20 a $1 / 0832 / 21$.

\section{Použité zdroje}

[1] MHATRE, Purva, Vidyadhar GEDAM, Seema UNNIKRISHNAN a Sanjeev VERMA. Circular economy in built environment - Literature review and theory development. Journal of Building Engineering [online]. 2021, 35 [cit. 2021-11-27]. ISSN 23527102.

[2] JOENSUU, Tuomo, Roosa LEINO, Jukka HEINONEN a Arto SAARI. Developing Buildings' Life Cycle Assessment in Circular Economy-Comparing methods for assessing carbon footprint of reusable components. Sustainable Cities and Society [online]. 2021 [cit. 2021-11-27]. ISSN 22106707.

[3] KAMALI, Mohammad, Kasun HEWAGE a Rehan SADIQ. Conventional versus modular construction methods: A comparative cradle-to-gate LCA for residential buildings. Energy and Buildings [online]. 2019, 204 [cit. 2021-11-27]. ISSN 03787788.

[4] JOENSUU, Tuomo, Roosa LEINO, Jukka HEINONEN a Arto SAARI. Developing Buildings' Life Cycle Assessment in Circular Economy-Comparing methods for assessing carbon footprint of reusable components. Sustainable Cities and Society [online]. 2021 [cit. 2021-11-27]. ISSN 22106707.

[5] EAST, Andrew John. What is a carbon footprint? An overview of definitions and methodologies. In: Vegetable industry carbon footprint scoping study_Discussion papers and workshop, 26 September 2008. Horticulture Australia Limited. 2008.

[6] ŠTEVO, Stanislav. Uhlíková stopa bývania v globalizovaných domoch. TZB Haustechnik. roč, 25: 16-20.

[7] AMOO, Leye M. a R. LAYI FAGBENLE. Climate change in developing nations of the world. Applications of Heat, Mass and Fluid Boundary Layers [online]. Elsevier, 2020, 2020, s. 437-471 [cit. 2021-11-27]. ISBN 9780128179499.

[8] SHINE, Keith P. The global warming potential - the need for an interdisciplinary retrial. Climatic Change [online]. 2009, 96(4), 467-472 [cit. 2021-11-27]. ISSN 0165-0009.

[9] KRAJCSOVICS, Lorant, Henrich PIFKO a Tatiana PIFKOVÁ. Ukážka energetickej efektívnosti a využitie obnovitel'ných zdrojov energie na príklade verejných budov. Zručnosti a príklady. Národný školiaci materiál (CEC5, 3sCE412P3).

[10] PIFKO, Steven, Diego JANCHES, Sigrid CLOSE, Jonathan SPARKS, Takuji NAKAMURA a David NESVORNY. The Meteoroid Input Function and predictions of mid-latitude meteor observations by the MU radar. Icarus [online]. 2013, 223(1), 444-459 [cit. 2021-11-27]. ISSN 00191035.

[11] DWAIKAT, Luay N. a Kherun N. ALI. Green buildings life cycle cost analysis and life cycle budget development: Practical applications. Journal of Building Engineering [online]. 2018, 18, 303-311 [cit. 2021-11-27]. ISSN 23527102.

[12] ATMACA, Adem. Life-cycle assessment and cost analysis of residential buildings in South East of Turkey: part 2 - a case study. The International Journal of Life Cycle Assessment [online]. 2016, 21(7), 925-942 [cit. 2021-11-27]. ISSN 0948-3349.

[13] ISLAM, Hamidul, Margaret JOLLANDS a Sujeeva SETUNGE. Life cycle assessment and life cycle cost implication of residential buildings - A review. Renewable and Sustainable Energy Reviews [online]. 2015, 42, 129-140 [cit. 2021-11-27]. ISSN 13640321. 